\title{
Criminogenic risks of irregular migration in conditions of armed conflict in Ukraine
}

\author{
Riesgos criminógenos de la migración irregular en condiciones \\ de conflicto armado en Ucrania
}

\section{Riscos criminogênicos de migração irregular em condições de conflito armado na Ucrânia}

\author{
Oleksii M. Lytvynov ${ }^{1}$ \\ Yurii V. Orlov ${ }^{2}$ \\ Andrei M. Yashchenko3 \\ Kseniya V. Yurtayeva ${ }^{4}$
}

Received: February $22^{\text {th }}, 2021$

Accepted: March $28^{\text {th }}, 2021$

Published: July $6^{\text {th }}, 2021$

How to cite this article:

Oleksii M. Lytvynov, Yurii V. Orlov, Andrei M. Yashchenko \& Kseniya V. Yurtayeva. Criminogenic risks of irregular migration in conditions of armed conflict in Ukraine. DIXI, vol. 23, $n^{\circ}$. 2, julio-diciembre 2021, 1-25. DOI: https://doi.org/10.16925/2357-5891.2021.02.09

Research article. https://doi.org/10.16925/2357-5891.2021.02.09

\footnotetext{
Doctor of Law, Professor, Honored Worker of Education of Ukraine, Head of the Department of Criminal Law and Criminology of the Faculty № 1, Kharkiv National University of Internal Affairs, Kharkiv, Ukraine.

E-mail: lytvynovalex@gmail.com

ORCID: https://orcid.org/0000-0003-2952-8258

2 Doctor of Law, Professor, Professor at the Department of Criminal Law and Criminology of the Faculty № 1, Kharkiv National University of Internal Affairs, Kharkiv, Ukraine.

E-mail: orlov1284@gmail.com ORCID: https://orcid.org/0000-0003-1981-0794

3 Doctor of Law, Professor, Professor at the Department of Criminal Law and Criminology of the Faculty № 1, Kharkiv National University of Internal Affairs, Kharkiv, Ukraine.

E-mail: ua.andr.iash@gmail.com ORCID: http://orcid.org/0000-0003-3956-3487

4 Candidate of Law, Associate Professor, Associate Professor at the Department of Criminal Law and Criminology of the Faculty № 1, Kharkiv National University of Internal Affairs, Kharkiv, Ukraine.

E-mail: yurtayeva@gmail.com
}

ORCID: http://orcid.org/0000-0002-6096-2020 


\section{Abstract}

The purpose of the paper is to comprehend and examine dimensions of irregular migration, namely its criminogenic and victimological sources, and its background influence on criminal processes in conditions of armed conflict in Ukraine. Results of the study allow us to draw a sound conclusion that irregular migration poses a number of criminogenic risks to Ukrainian national security, as well as to the rights and freedoms of Ukrainian citizens, especially of those who remain or arrive to the occupied territories. The research ascertains that criminogenic potential of migration may be viewed from two related perspectives associated with the phenomenon of migrants' criminality and migrants as potential or real victims of crime. The research outlines the factors providing a favourable environment for engaging irregular migrants into criminal activities. Based on the recent amendments to the Criminal Code of Ukraine and on current criminal statistics, the research ascertains the links of ethnic minority criminality and mercenary activities with irregular migration in Ukraine. The research provides arguments that internally displaced persons can be viewed as a contemporary type of intra-state migration that poses additional criminogenic hazards in the conditions of armed conflict in Ukraine. Practical implications of the study lay in the recommendations for decreasing the risks of irregular migration, in conditions of armed conflict in Ukraine, and defined the following: Resolving the issue on the legal status of the armed conflict in Eastern regions of Ukraine, as well as recognizing Lugansk Public Republic and Donetsk Public Republics as terrorist's organizations on the national level. Reinforcing suppression of all kinds of smuggling, including international. The same way, with the occupied territories, providing legal and psychological support to the victims of human trafficking and to the internally displaced persons; intensification of awareness-raising campaign on the risks on migrant smuggling and human trafficking among Ukrainian citizens, including the population of the affected conflict regions; reinforcing the fight against organized crime, and paying a specific attention at counteracting ethnic minority criminality. Finally, enhancing organizational bases and legal support in the field of counteracting irregular migration.

Keywords: Criminality, criminogenic risks, counteracting framework, enhancement, irregular migration.

\section{Resumen}

El objetivo del artículo es comprender y examinar las dimensiones de la migración irregular, es decir, sus fuentes criminógenas y victimológicas, y su influencia de fondo en los procesos delictivos en condiciones de conflicto armado en Ucrania. Los resultados del estudio permiten llegar a la sólida conclusión de que la migración irregular plantea una serie de riesgos criminógenos para la seguridad nacional ucraniana, así como para los derechos y libertades de los ciudadanos ucranianos, especialmente de los que permanecen o llegan a los territorios ocupados. La investigación determina que el potencial criminógeno de la migración puede considerarse desde dos perspectivas relacionadas, asociadas al fenómeno de la criminalidad de los migrantes y a los migrantes como víctimas potenciales o reales de la delincuencia. La investigación esboza los factores que proporcionan un entorno favorable para involucrar a los migrantes irregulares en actividades delictivas. Basándose en las recientes enmiendas al Código Penal de Ucrania y en las estadísticas criminales actuales, la investigación determina los vínculos de la criminalidad de las minorías étnicas y las actividades mercenarias con la migración irregular en Ucrania. La investigación aporta argumentos para considerar a los desplazados internos como un tipo contemporáneo de migración intraestatal que plantea riesgos criminógenos adicionales en las condiciones del conflicto armado en Ucrania. Las implicaciones prácticas del estudio radican en las recomendaciones para disminuir los riesgos de la migración irregular, en condiciones de conflicto armado en Ucrania, y definen lo siguiente Resolver la cuestión del estatus legal del conflicto armado en las regiones orientales de Ucrania, así como reconocer a las Repúblicas Públicas de Lugansk y Donetsk como organizaciones terroristas a nivel nacional. Reforzar la represión de todo tipo de contrabando, incluido el internacional. Del mismo modo, con los territorios ocupados, proporcionar apoyo legal y psicológico a las víctimas de la trata de 
personas y a los desplazados internos; intensificar la campaña de concienciación sobre los riesgos del tráfico de migrantes y la trata de personas entre los ciudadanos ucranianos, incluida la población de las regiones afectadas por el conflicto; reforzar la lucha contra la delincuencia organizada, y prestar una atención específica a la lucha contra la delincuencia de las minorías étnicas. Por último, mejorar las bases organizativas y el apoyo jurídico en el ámbito de la lucha contra la migración irregular.

Palabras clave: criminalidad, riesgos criminógenos, marco de lucha, mejora, migración irregular.

\section{Resumo}

O objetivo do documento é compreender e examinar as dimensões da migração irregular, ou seja, suas fontes criminogênicas e vitimológicas, e sua influência de fundo nos processos criminais em condições de conflito armado na Ucrânia. Os resultados do estudo nos permitem tirar uma conclusão sólida de que a migração irregular representa uma série de riscos criminogênicos para a segurança nacional ucraniana, assim como para os direitos e liberdades dos cidadãos ucranianos, especialmente daqueles que permanecem ou chegam aos territórios ocupados. A pesquisa verifica que o potencial criminogênico da migração pode ser visto de duas perspectivas relacionadas associadas ao fenômeno da criminalidade dos migrantes e dos migrantes como vítimas potenciais ou reais da criminalidade. A pesquisa delineia os fatores que proporcionam um ambiente favorável para o envolvimento de migrantes irregulares em atividades criminosas. Com base nas recentes emendas ao Código Penal da Ucrânia e nas estatísticas criminais atuais, a pesquisa verifica as ligações da criminalidade de minorias étnicas e atividades mercenárias com a migração irregular na Ucrânia. A pesquisa fornece argumentos de que pessoas deslocadas internamente podem ser vistas como um tipo contemporâneo de migração intra-estatal que apresenta riscos criminogênicos adicionais nas condições do conflito armado na Ucrânia. As implicações práticas do estudo residem nas recomendações para diminuir os riscos de migração irregular, em condições de conflito armado na Ucrânia, e definiram o seguinte: Resolver a questão sobre o status legal do conflito armado nas regiões orientais da Ucrânia, bem como reconhecer a República Pública de Lugansk e as Repúblicas Públicas de Donetsk como organizações terroristas em nível nacional. Reforçar a repressão de todos os tipos de contrabando, incluindo o internacional. Da mesma forma, com os territórios ocupados, fornecendo apoio jurídico e psicológico às vítimas do tráfico de pessoas e às pessoas deslocadas internamente; intensificação da campanha de conscientização sobre os riscos do contrabando de migrantes e do tráfico de pessoas entre os cidadãos ucranianos, incluindo a população das regiões de conflito afetadas; reforço da luta contra o crime organizado, e atenção específica no combate à criminalidade de minorias étnicas. Por fim, o reforço das bases organizacionais e do apoio jurídico no campo da luta contra a migração irregular.

Palavras-chave: Criminalidade, riscos criminogênicos, estrutura de combate, melhoria, migração irregular.

\section{INTRODUCTION}

In a contemporary society explicitly accepting human rights values entailing its wide range of freedoms, including a freedom of movement, the concept of irregular migration is highly debated. The philosophy of open markets and freedom of expression implies the provision of almost unrestricted possibilities to the members of global society, although complemented by basic restraints concerning general safety measures and maintaining public order. However, in practice the implementation of such idealized concepts come in conflict with given limited social and natural 
resources, significant disparity in the level of development between countries and subsequent need for supporting national security of individual states. Thus, the premises of irregular migration intimately arise from controversies of the modern globalized world.

There is no clear or universally accepted definition of irregular migration. Frequently irregular migration is used as a synonym for illegal migration, which is not fully accurate: The entry into a country on a tourist visa can be legal, staying after the expiring of the visa is illegal and is irregular. From the perspective of destination countries, irregular migration is a matter of entry, stay or work in a country without the necessary authorization or documents required under (im)migration regulations. From the perspective of the departing country, the irregularity is relevant in cases when a person crosses an international boundary without a valid passport or travel document or does not fulfil the administrative requirements for leaving the country. However, nowadays the international community tends to restrict the use of the term "illegal migration" to cases of the smuggling of migrants and human trafficking. Therefore, in a practical perspective, irregular migration comprises:

- Persons who illegally cross state borders including those using or producing a fraudulent travel or identity documents;

- Persons who at first legally entered a country, but stay illegally after the expiring of his/her permit.

From a criminological perspective, the relevance of irregular migration comprises among others the following facets: Ascertaining the point when irregular migration intercepts "the crime zone", defining the modern hazards posed by irregular migration, defining triggering factors for the process, of transforming a migrant into a criminal or into a victim of a crime.

In recent years, Ukraine faced the ever-growing negative consequences in its political, economic and social life triggered by the armed conflict erupted in the Lugansk and Donetsk regions in 2014. The outbreak of the armed confrontation exacerbated several traditional risks to national security. Irregular migration is a top issue on this list. In this research, we made an effort to analyze the traditional risks of irregular migration in Ukraine and reassess them in the light of ongoing armed conflict and general criminogenic trends of irregular migration worldwide. 


\section{METHODOLOGY}

The present paper analysis utilizes basic theoretical foundations of criminogenic risks of irregular migration in conditions of armed conflict in Ukraine. Nowadays, any research should be based on the use of appropriate scientific methods, the application of which makes it possible to achieve the purpose, to justify the conclusions scientifically, and to propose appropriate ways to solve the problem under study. The methodological basis includes a set of general and specific methods of scientific cognition, due to the fact that it is an interdisciplinary approach, where the basis of the theoretical and methodological component are the fundamental provisions of the theory in the field criminology (the scientific study of crime and criminals).

The method of analysis was used by the authors of the article to study the objective state of criminogenic risks of irregular migration in conditions of armed conflict in Ukraine. The systematic approach as a general scientific method has allowed to define the problematic issues related to criminogenic risks of irregular migration in conditions of armed conflict in Ukraine. The method of documentary analysis and the analytical method were used during the scientific substantiation of theoretical conclusions. All of these methods are applied in interdependence and interconnection.

\section{RESULTS AND DISCUSSION}

\subsection{The phenomenon of the contemporary migration and its criminogenic potential}

In the contemporary globalized world, migration is perceived as a widespread phenomenon. According to the United Nations official data, in 2000-2017 the estimated number of international migrants worldwide increased 49\%, from 172.6 million in 2000 to 258 million in 2017 (see Figure 1). The International Organization for Migration (IOM) estimates that the flows of migration increase annually with $2.2 \%$ in 2000 to $3.5 \%$ in 2017. However, data provided by international organizations do not offer a precise picture of contemporary migration flows. Currently, only 45 countries report migration flow data to the United Nations. Governments use different concepts, definitions and data collection methodologies to compile statistics on migration flows. So, the cited numbers of international migration flows are rather an approximation.

1 Migration Data Portal. World Key Migration Statistics. 


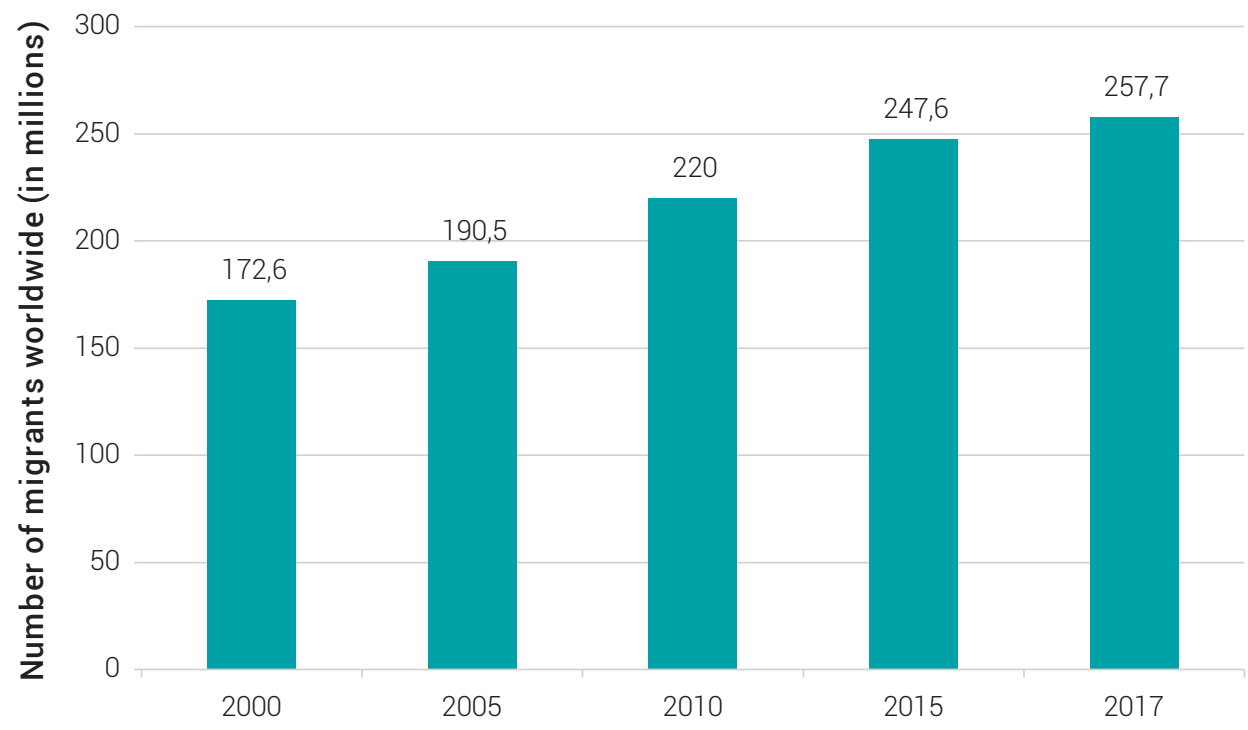

Figure 1. Growth of international migration flows between 2000 and 2017 (in millions²) Source: Own preparation.

In the United Nations analytical report on human mobility released in 2009, international experts presented conservative estimates of migration. Applying a comprehensive understanding of modern global peoples' flows, including international and intra-state migrants, both forced and voluntary, they estimated 740 million as internal migrants and 215 million as international migrants, not counting tourists. Research findings indicated that migrants did not only move from developing to developed countries (approximately one third of the total number of international migrants), but also from one developing country to another, as well as between developed countries. ${ }^{3}$ The United Nations monitoring study outlined various reasons for migration not limited to unsatisfactory economic or political circumstances in the country of origin, but also encompassing personal reasons (family reunion, marriage), labor or educational migration, (high) crime rate, business, medical/health reasons, etc.

Considering the assumptions mentioned above, migration can be viewed as unavoidable in the contemporary world, a phenomenon that has a dramatic economic, political and social influence on the development of the international community as a whole and of separate states in particular. Foreshadows of migration are frequently

2 Based on the data from Migration Data Portal. Available at: https://migrationdataportal. org/?i=stock_abs_\&t=2017

3 United Nations. HUMAN DEVELOPMENT REPORT. "OVERCOMING BARRIERS: HUMAN MOBILITY AND DEVELoPMENT". United Nations Publications. (2009). Pg. 1-2. 
underestimated. Therefore, it is important to draw attention to criminogenic potential of the contemporary migration and its correlation with the concept of irregular migration.

Increased population mobility triggered a number of problems connected with the inability of traditional state-based criminal justice systems to deal with ever-growing cross-border criminogenic hazards. Single perpetrators and even organized criminal groups of ten stay undetected using possibilities of modern transportation system, lacunas in domestic legislation and drawbacks of international crime control system. In this connection, criminogenic potential of migration may be viewed from two related perspectives:

1. Migrants as criminals, or in other words, the phenomenon of migrants' criminality, which encompass:

a) Migration and irregular migration as an indispensable part of a cross-border crime schemes: Such as human trafficking, smuggling, and international terrorism;

b) Migrants and irregular migrants crossing the border with a sole intent to commit a crime or become associated in criminal activity (ethnic minority criminal groups, crime against national security, mercenarism, etc.):

c) Irregular migrants due to their illegal status become vulnerable to get involved into different criminal activities or commit crimes during the process of infiltrating a foreign community (falsification of documents, smuggling and even hijacking):

2. Migrants as potential or real victims of crime: In several instances, migrants themselves become victims of various criminal activities (migrants smuggling, labor and sex exploitation, assaults, discrimination, hate crimes) on the stage of crossing the border or upon their arrival to a foreign community.

Consequently, the criminological concept of irregular migration encompasses the full range of criminogenic hazards of the phenomenon of the contemporary migration, and extends beyond its strict legal definition. 


\subsection{Framework of counteracting irregular migration in Ukraine: Legislative and practical dimensions}

Problems caused by irregular migration are not new to the Ukrainian society. Its geographical position and traditional multi-nationality of the population of Ukraine historically put it at the crossroad in international migration flows. The present population of Ukraine comprises more than 50 national groups. According to international sources, the officially reported number of migrants in Ukraine in 2017 is estimated at five million persons, which equates to $2.5 \%$ of the whole registered international flow of migrants. ${ }^{4}$

Erupted in 2014, the armed conflict in the Lugansk and Donetsk regions of Ukraine provoked novel massive intra-state and international migration flows fleeing from the conflict zone and the Crimea to other regions of Ukraine, this during the last four years. A large number of Ukrainian citizens moved from the conflict zone to other states (forced migrants) and have not been officially established to date. Actually becoming refugees in their native country and also abroad, lacking governmental support, in each of the mentioned situations, the citizens of Ukraine became vulnerable to several criminogenic risks.

Another trend in modern migration flows in Ukraine directly relates to the practical inability of Ukrainian state to control its border in the conflict zone, and to the illegal movement of persons and items across the eastern state border. Illegal crossing the state border or doing so with a criminal intent contribute to the growth of such existing criminal phenomena of ethnic minority criminality, smuggling of dangerous items, proliferation of terrorism, and mercenarism.

Taking into account the aggravation of the social and political situation in Ukraine, the legal framework of counteracting irregular migration has undergone essential amendments during the last years. Suffering from the conflict in the Lugansk and Donetsk regions, the Ukrainian government was not able to maintain law and order in these regions and had to restrict its international obligations in this sphere. Thus, on 20 October 2015 the Ukrainian government filed a Communication ${ }^{5}$ to the United Nations officially recognizing its inability to enforce obligations under Protocol against the Smuggling of Migrants by Land, Sea and Air, supplementing the United Nations Convention against Transnational Organized Crime $(2000)^{6}$ until the complete

4 Migration Data Portal. Ukraine Key Migration Statistics.

5 Protocol against the Smuggling of Migrants by Land, Sea and Air, supplementing the United Nations Convention against Transnational Organized Crime. New York, 15 November 2000. Ukraine: Communication (20 October 2015).

6 Protocol against the Smuggling of Migrants by Land, Sea and Air, supplementing the United Nations Convention against Transnational Organized Crime (15 November 2000). 
restoration of the constitutional law and order, and until the effective control by Ukraine over the occupied territory. With such legal procedures, the Ukrainian state abdicated its responsibility for events taking place within the occupied regions. Therefore, migration flows were triggered because of the lack of safety and rule of law, public administration and law enforcement in the regions of the armed conflict. Accordingly, from 2015 irregular migration proceeding both to and from the occupied territories is not included into official statistics, therefore neither is properly studied, nor controlled.

Regarding legislation, Ukraine has changed a permit regime on the state border and frontiers with the occupied territories, and has provided criminal and administrative liability for a number of infringements in this sphere. Accordingly, in 2014 Ukraine provided administrative liability for violations connected with entering and exiting the conflict zone. ${ }^{7}$ The same year, Ukraine also provided criminal liability for violations of the procedure of entry and exit of temporary occupied territory with intent to cause harm to public interests (Art. 332-1 of the Criminal Code). In 2018, this was followed by establishing criminal liability for crossing the state border of Ukraine with intent to cause harm to public interests, or by a person who is prohibited from entering the territory of Ukraine, or by representatives of military force and law enforcement units of the aggressor country (Art. 332-2 of the Criminal Code). This initially protective measure has changed the official concept of irregular migration in Ukraine and has extended measures of its criminal persecution. So far, there is no case law on Art. 332-2 of the Criminal Code of Ukraine; but available criminal cases on Art. 332-1 of the Criminal Code of Ukraine indicate that courts interpret public interest very broadly, for instance as illegal food product trading with the occupied territories. ${ }^{8}$ This means that from 2018 the concept of irregular migration encompass illegal entering the country with intent to cause harm to public interests, that virtually equates to intent to commit any criminal or administrative offense. It has been quite appropriately suggested to restrict intent to cause harm to public interests, and to committing crimes against the national security of Ukraine and public order, ${ }^{9}$ but so far this norm has not been amended.

7 The mentioned administrative offenses include: Violations of the procedure of entry and exit of the temporary occupied territory (Art. 204-2 of the Code on Administrative Offenses), violations of the procedure of moving goods to or out of the regions in which antiterrorist operation is carried out (Art. 204-3 of the Code on Administrative Offenses), violation of the procedure of entry and exit of the regions in which antiterrorist operation is carried out (Art. 204-4 of the Code on Administrative Offenses).

8 See, for instance, Indictment of Dryzhkivdskij City Court from 13-01-2016; Indictment of Appeal Court of Donetsk region 08-12-2016.

9 A. A. Nikitin. CRIMINAL RESPONSIBILITY FOR VIOLATION OF PROCEDURE FOR TEMPORARY OCCUPIED TERRITORY OF UKRAINE ENTRY AND EXIT FROM IT. National Academy of Internal Affairs. (2018). Pg. 126. 
Obviously, issuing only prohibitive measures does not resolve the issue of irregular migration. In an organizational aspect, on 12-7-2017 the government of Ukraine established the legal provision of counteracting irregular migration by adopting the Strategy of the state migration policy of Ukraine for the period up to $2025 .{ }^{10}$ It outlined the main risks of irregular migration in contemporary conditions, including uncontrolled labor immigration, the adverse trends in rapid decrease of the ethnic population of Ukraine, and the problem of stateless persons and refugees. The Strategy ascertained the tendency of growth of irregular migration in Ukraine starting from 2015. It predicted an aggravation of the situation in conditions of extensive anti-terrorist measures taken in the Eastern regions of Ukraine, and the growth of the number of internally displaced persons from the territories of the armed conflict as a problem requiring specific legal regulation. Therefore, it is totally inconsistent that the Plan of action for the period of 2018-2021 adopted for the realization of the mentioned Strategy ${ }^{11}$ does not include any counteracting actions for irregular migration.

Despite predicted hazards outlined in the Strategy of the state migration policy of Ukraine for the period up to 2025, official statistics provide optimistic data about the rate of irregular migration in Ukraine. On the briefing, the head of the Migration Service of Ukraine, Maxim Sokolyuk, reported that in 2017 during special operations "The Migrant" and "The Border" 9.678 irregular migrants were detected, and almost 9.264 of them were returned to their country of origin.12 According to the comprehensive report of Olga Derkach, the senior officer of the Administration of the State Border Guard Service of Ukraine, the migration situation is not threatening and irregular migration has not become a significant problem for the Ukrainian state. The official report states that, in 2017, Ukraine observed the trend of a decreasing number of illegal migrants detained for trying to enter the European Union illegally. Most of the illegal migrants were detained on the border with Hungary - in 3.2 times (nine months in 2017 and 104.9 months in 2016), which can be explained by the changes of migration policy stricter than before 2015. At the same time, there was an increase of the number of migrants detained at the border with Poland, Slovakia and Romania. Regarding these trends, Olga Derkach refers not only to the changes of migration flows, but also to the

10 Strategy of the state migration policy of Ukraine for the period up to 2025 affirmed by Resolution of the Cabinet of Ministers of Ukraine from 12.07.2017 № 482-p. Available at: http://zakon.rada.gov.ua/laws/show/482-2017-\%D1\%80

11 On affirming the Plan of Action for the period of 2018-2021 adopted for realization of the Strategy of the state migration policy of Ukraine for the period up to 2025: Resolution of the Cabinet of Ministers of Ukraine from 29.08.2018 № 602-p. Available at: http:// zakon.rada.gov.ua/laws/show/602-2018-\%D1\%80

12 Head of the Migration Service of Ukraine Maxim Sokolyuk presented a public report on the activity of the State Migration Service of Ukraine in 2017. 
consequences of effective enhancement of the border regime and the fulfilment of joint coordination measures. ${ }^{13}$

At the same time, experts and international organizations express concern over the growing number of irregular migrants in Ukraine. Research estimations indicate that a much larger number of international migrants cross the Ukrainian borders annually than was usually assumed - from 45 to 50 thousand migrants. ${ }^{14}$ Therefore, the official affirmation that Ukrainian borders are under rigorous governmental control sounds unconvincingly. In our opinion, the government of Ukraine tends to ignore the situation given a substantial number of foreign citizens present in the so called "grey zone" (demilitarized neutral zone on the demarcation line between the conflict zone and peaceful territories of Ukraine), as well as in the uncontrolled territories in Eastern Ukraine. Their presence poses a potential threat to the rest of Ukraine. The gravity of the current situation is fully substantiated by strengthened criminal and administrative liability for illegal crossing the frontiers with the temporary occupied territory and the state border mentioned above. At the same time, such a situation indicates that the organizational framework for counteracting irregular migration in Ukraine doesn't reflect tendencies of this phenomenon in conditions of armed conflict. Its policy needs to be modified and enhanced urgently. It also should be taken into account that hazards mentioned above posed by uncontrolled intra-state and irregular migration are multiplied by the new ever-growing challenges for the Ukrainian government that immediately refer to:

- Unprecedented growth of terrorist threats in Ukraine: In the Global Terrorism Index in 2015 Ukraine has risen to the $12^{\text {th }}$ place, compared to the $51^{\text {st }}$ place in 2014; in 2018 Ukraine lands on the $21^{\text {st }}$ place in Global Terrorism Index. ${ }^{15}$ Similar trends are to be found in the national criminal statistics: With the outbreak of the internal armed conflict, the rate of terrorist crimes in 2014 has grown almost 200 times compared to 2013 (from seven detected terrorist offenses in 2013 to 1,391 terrorist offenses in 2014). The same trend is continuing in 2018 (1,181 terrorist offenses have been detected in 2018). ${ }^{16}$

13 International Organization for Migration. ILLEGAL MIGRATION IN EASTERN EUROPE AND UKRAINE. SPECIAL REPORT. IOM Publications. (2018). Pg. 16-17.

14 T. A. Denisova. Migration Processes in Ukraine: Present State and Issues of Illegal Migration. StATE AND REgIONS. Legal SERIES 2. 2016. Pg. 74.

15 Reports. Institute for Economics and Peace.

16 Statistic information of the Office of the Attorney General of Ukraine. 
- Proliferation of extremism and radical attitudes: Starting from 2014 the rate of crimes against national security has gone up 40 times (eight offenses were detected in 2013, 325 offenses in 2017 and 428 offenses in 2018), ${ }_{17}^{7}$

- Growth of illegal circulation of all kinds of weapons and explosives: At the pre-conflict period in 2013 the police seized 3,5 thousand illegal weapons, in 2017 this number reached five thousand and 2,3 thousand of the illegal weapons was seized during the first six months of 2018; moreover, according to the Chief Military Procurator of Ukraine, A. Matios, there is an estimated amount of 400 thousand illegal weapons that has flown in from the conflict zone and came in the hands of the civilians. ${ }^{18}$

The dramatic growth of the crime rate includes the rate of aggressive crimes. Official statistic does not indicate the growth of crime rate in 2017 and 2018 compared to the pre-conflict period (563.560 offenses detected in 2013, 523.911 offenses in 2017, and 487.133 offenses in 2018), ${ }^{19}$ but taking into account that starting from 2014 official crime statistic does not include Donetsk, Lugansk regions and the Crimea, it may be concluded that the growth of crime rate is at least $15-20 \%$ at the analyzed period. According to $\mathrm{O}$. Baganets, other reasons for official crime statistic to decrease are the following: Desire of current law enforcement officials to deny crime registration, especially concerning crimes committed in non-obvious circumstances, and reluctance of citizens to report crimes to the police due to their distrust to the law enforcement system and their unwillingness to be engaged in red tapes of criminal process. ${ }^{20}$

These outlined factors have significant impact on the political, economic and social situation in the country and can be considered as a favorable environment for engaging irregular migrants into different kinds of criminal activities, including ethnic minority criminality, smuggling, human trafficking and other severe offenses against public order, as well as becoming victims of crimes. Taking into account its high criminogenic potential, the issue of internally displaced persons also requires particular attention.

\section{Ibidem.}

18 Don't move or you might be shot out: why Ukrainians en masse purchase weapons? RBK-Ukraine. 25.07.2018.

19 Statistic information of the Office of the Attorney General of Ukraine.

20 O. Baganets. Crime without Borders. Crime Statistic, its Structure and Dynamics on the Territory of Ukraine in 2017 (Comparative to Crime Rate in 2009, 2010, 2013-2016). Available at: http://baganets.com/blogs-baganets/zlochinn-st-bez-kordon-v.html 


\subsection{The links between irregular migration and ethnic minority criminality}

One of the usual problems associated with irregular migration is ethnic minority criminality, which nowadays experiences a new significant growth in Ukraine. ${ }^{21}$ Ethnic criminality typically takes organized forms and has several peculiar features. Established on ethnic grounds, organized criminal groups are more close-knit, aggressive and dangerous compared to transnational criminal groups. ${ }^{22}$ During the last ten years, it was recorded a considerable growth of ethnic organized groups in Ukraine, among which can be outlined Chechen, Gypsy, Georgian, Azerbaijan, Armenian, Vietnamese, Chinese, Nigerian and Tatar organized criminal groups. Most of them have a specialization, for instance: Vietnamese criminal groups specialize in contraband and migrant smuggling; Chechen criminal groups specialize in fraud, robberies and auto thefts; Nigerian criminal groups and groups from South-East Asia specialize in drug smuggling and drug trafficking ${ }^{23}$. One of the typical criminogenic features of migrants is their socio-economic ease in transforming legal activities into their illegal forms. As a response, stoked by frequently emphasized mass media coverage, the general public forms an intolerant attitude towards migrants perceiving them as potential criminals.

Ethnic criminal groups are usually closed-off, their members are commonly united, not only by a group cohesion, but also by family links. They frequently have clan or bloodline-based structure. Most of their members have already the Ukrainian citizenship, but they also preserve close contacts with criminal circles in the countries of their origin and with ethnic diasporas in other foreign countries that allows them to recruit new members and maintain cross-border criminal activities, including smuggling of prohibited items and migrant smuggling.

Counteracting illegal activity of ethnic-based crime is extremely complicated due to their closed nature, linguistic and cultural features, which are practical difficulties connected within filtrating undercover agents into their community. Therefore, criminal activities of ethnic criminal groups have a high level of latency. Nevertheless, the detection rate of ethnic group criminality due to the activities of the Ukrainian law

21 V. G. Sevruk \& N. K. Makarenko. Counteracting Ethnic Organized Crime Activity by Law Enforcement Organs of Ukraine: Ukrainian and International Experience. SCIENTIFIC BULLETIN OF NATIONAL ACADEMY OF INTERNAL AFFAIRS 103. 2017. Pg. 160.

22 V. G. Sevruk. The Notion and Criminal Legal Characteristic of "Ethnic Criminality" in Ukraine. JOURNAL OF ADVOCACY ACADEMY OF UKRAINE 24. 2014. Pg. 85.

23 S. Kozlyuk. Criminality with Accent. Are there Ready for use Recipes for Counteracting Ethnic Criminal Groups. 17 July 2018. Available at: http://cripo.com.ua/?sect_ $\mathrm{id}=3$ \&aid $=249622$ 
enforcement is slowly increasing: In 2016 there were detected six ethnic-based organized groups; in 2017 their number reached nine; for the first eight months of 2018 this amount equaled to $15 .{ }^{24}$ After the termination of the Organized Crime Departments in February 2015 and transferring its functions to the newly established National Police of Ukraine as a part of reform of law enforcement agencies, such increasing statistic demonstrates progressive changes in activity of the National Police of Ukraine in the field of counteracting ethnic organized criminal groups.

On the other hand, cross-border ethnic- or religious-based criminal groups continue to transit through Ukraine. For example, in 2017 the Kharkiv intelligence services of the Security Service of Ukraine uncovered and terminated activity of several transit channels of foreign fighters of international terrorist organization ISIL (Islamic State of Iraq and the Levant). Four detected criminals originating from Middle-East countries used a private apartment for a temporary hideout for the members of this organization and their further routing to Syria-Iraq zone of warfare. In another case, several internationally wanted supporters of ISIL, citizens of the former USSR states, were detected in the Kiev and Dnipropetrovsk regions by the officers of the Security Service of Ukraine. ${ }^{25}$

Deprived of the ability to maintain law and order on large areas of its territory, Ukraine remained to be an attractive transnational route for terrorists and cross-border activities of other criminal groups. In February 2018, the Security Service of Ukraine detected and terminated the activities of an organized criminal group specializing in legalizing irregular migrants, including activists of ISIL, in Ukraine. Later on, in April 2018 the Security Service of Ukraine arrested five participants of international terrorism groups specializing in legalizing irregular migrants through Ukraine by activists of international terrorist organizations and providing them assistance in crossing the European Union (EU) border. ${ }^{26}$ According to the Security Service of Ukraine, "the grey zone" and conflict zone are used by organized criminal groups for migrants smuggling. For instance, in 2017 the Security Service of Ukraine blocked the activities of an organized criminal group headed by a ressortissant from the Middle-East

24 Report on the result of counteracting organized groups and criminal organizations, 2016, 2017 and 2018.

25 National Institute of Strategic Research. International Terrorism: Threats to Ukraine. Analytical Note. Available at: www.niss.gov.ua/content/articles/files/mizhnar_teror-17f29.pdf

26 The Security Service of Ukraine blocked legalizing participants of international terrorist organizations. 
specializing in migrant smuggling from and to Ukraine through the Lugansk region. A part of irregular migrants stayed in Kharkiv and worked in illegal sewing workshops. ${ }^{27}$

Recent changes in the structure of ethnic- and religious-based criminal groups made it extremely difficult to terminate their activities. Instead of a traditional pyramidal structure, the mentioned criminal groups emulate independent cell structures that makes their leaders and coordinators practically untraceable for law enforcement. ${ }^{28}$

The State Border Service of Ukraine informs that, compared to the previous year in 2018, irregular migration has already grown 20\%. ${ }^{29}$ At the same time, experts conclude that nowadays most of the migrants do not see Ukraine as a destination country due to the quite low living standard compared to the neighboring countries. Apparently, this process is also influenced by inner EU migration regulations and policies: In recent years sufficiently lenient migration regulation in the EU allowed irregular migrants to entry the Schengen area directly without transitional states. Reinforcing EU migration regulations in 2017 may have significantly changed this situation and provided additional migration pressure on neighboring (non-EU) countries, including Ukraine.

Today, citizens of such countries as Vietnam, Afghanistan, India, Sri Lanka and countries of the former USSR still perceive Ukraine as a transit country on their way to illegal infiltrating Eu borders. A common scenario in this regard is that (irregular) migrants enter Ukraine by legitimate invitation of educational institutions with second or third level of accreditation. Accurate verification uncovers that such invitations have a regular origin but the so-called "students" are not found at the educational institutions and subsequently are detected at the EU borders. Law enforcement officers often complain of a lack of capacity to counteract such seemingly legitimate actions, but present legal framework does not provide any possible counteractive measures for this process, unless such actions are qualified as migrant smuggling (Art. 332 of the Criminal Code of Ukraine) or human trafficking (Art. 149 of the Criminal Code of Ukraine).

27 In Kharkiv region, the Security Service of Ukraine terminated activity of irregular migrant smuggling channels.

28 J. P. Bjelopera \& K. M. Finklea. Organized Crime: An Evolving Challenge for U.S. Law Enforcement. CRS Report for Congress. 2012. Pg. 18-22; S. Polo. How Terrorism Spreads: Information, Emulation, and the Spatial Diffusion of Ethnic and Ethnoreligious Terrorism. Available at: http://sites.psu.edu/pssi/wp-content/uploads/sites/12816/2015/11/ Polo-OPSC-0325.pdf

29 Ukraine is threatened by a Flow of Illegal Migration. What are Preconditions for This? [In Ukrainian]. Available at: https://nv.ua/ukr/world/geopolitics/ukrajini-zahrozhuje-navala-nelehalnikh-mihrantiv-jaki-je-peredumovi-dlja-tsoho-2481499.html 
In this regard, we support the opinion of Andrij Solodko, an expert of the analytical center CEDOS, who suggested that the fight against irregular migration should start not with migrants themselves, but with fighting corruption in migration services and court systems. At the same time, we also agree with Ognyev, who admits certain inconsistency in attributing criminal liability for migrants' smuggling. He reasonably suggests providing criminal liability not only for migrants' smuggling, but also for the organization and facilitation of the stay and transit of irregular migrants in Ukraine. ${ }^{30}$ Such lacuna in regulating criminal liability for migrants' smuggling clearly violates Ukrainian international obligation in this sphere. It can also be expected that providing such liability may subsequently decrease corruption level in this field.

\subsection{Internally displaced persons as the contemporary type of intra-state migration and its links with criminality}

A newly emerged crime furthering problem in Ukraine derives from internally displaced persons, who have been forced to flee from their homes trying to avoid the effects of armed conflict and political persecution. Internally displaced persons are not usually included into the category of irregular migrants, but a disturbing intra-state migration flow resulting from the armed conflict and the provision of criminal liability for violation of the procedure of entry and exit of temporary occupied territory require paying a particular attention to the criminogenic potential of internally displaced persons.

According to the official statistics of the Ministry of Social Policy of Ukraine, by December 2018 there are more than 1.5 million internally displaced persons from Crimea, Lugansk and Donetsk regions of Ukraine. ${ }^{31}$ Internally displaced persons are considered as a contemporary type of intra-state migration that typically accompanies armed conflicts and warfare. According to the report of the High Commissioner of the United Nations Refugee Agency (UNHCR), about 80\% of internally displaced persons from Lugansk and Donetsk regions and Crimea tend to remain closer to the regions of their origin and reside at their relatives', friends' or rent dwellings. ${ }^{32}$ In 2017 , most of internally displaced persons have settled in the following regions: Unoccupied

30 T. Y. Ognyev. ILLEGAL MIGRATION: CRIMINAL-LEGAL AND CRIMINOLOGICAL ASPECTS. Kyiv International University. (2017). Pg. 8.

31 1,513,574 internally displaced persons were recorded.

32 United Nations High Commissioner for Refugees. UNHCR urges Ukraine to establish central registration system as internal displacement tops 117,000. 5 August 2014. Available at: www.unhcr.org/news/latest/2014/8/53e0b3a59/unhcr-urges-ukraine-establish-central-registration-system-internal-displacement.html 
areas of Donetsk region, unoccupied areas of Lugansk region, Kiev, Kharkiv region, Dnipropetrovsk region, Kiev region and Zaporizha region (Table 1).

Table 1. Distribution of internally displaced persons in Ukraine per regions in $2017^{33}$

\begin{tabular}{|c|c|}
\hline Name of the region & Number of internally displace persons \\
\hline Donetsk region (unoccupied areas) & 538,407 \\
\hline Lugansk region (unoccupied areas) & 296,284 \\
\hline Kiev & 157,024 \\
\hline Kharkiv region & 121,808 \\
\hline Dnipropetrovsk region & 73,655 \\
\hline Kiev region & 61,162 \\
\hline Zaporizhia region & 54,188 \\
\hline Odessa region & 37,475 \\
\hline Poltava region & 26,315 \\
\hline Vinnytsa region & 14,860 \\
\hline Kherson region & 13,677 \\
\hline Cherkassy region & 12,882 \\
\hline Lviv region & 12,032 \\
\hline Sumy region & 11,109 \\
\hline Chernigiv region & 8,737 \\
\hline Mykolaiv region & 8,327 \\
\hline Kirovograd region & 7,617 \\
\hline Zhytomir region & 7,288 \\
\hline Khmelnitskiy region & 6,989 \\
\hline Ivano-Frankivsk region & 3,429 \\
\hline Zakarpattya region & 3,429 \\
\hline Rivno region & 3,236 \\
\hline Volyn region & 2,875 \\
\hline Ternopil region & 2.374 \\
\hline Chenivtsy region & 2,276 \\
\hline Total number of internally displaced persons & $1,487,455$ \\
\hline
\end{tabular}

Source: Own preparation.

Despite of numerous public and private initiatives aimed at supporting internally displaced persons, the latter reports the lack of proper governmental support,

33 Based on the data of the Ministry of Social Policy of Ukraine from the 7th of December 2017. Data retrieved from: Response of the Ministry of Social Policy of Ukraine to the request of Academician Stashis Scientific Research Institute for the Study of Crime Problems, National Ukrainian Academy of Law Sciences, from 21.03.2017 №34/o/208$17 / 221$ 
problems with employment and adaptation in the host communities. Such unsatisfactory situation at some instances results in picking up criminal lifestyle. Starting from 2014, the number of aggressive crimes in Ukraine has doubled, substantially increasing the number of property offenses, illicit arms trade, and acts of terrorism. Legal professionals attribute such boost in criminal statistics partly to criminal activity of internally displaced persons. For instance, interviews of more than 800 officers of the National Police identified that $57 \%$ of them had previously encountered internally displaced persons as delinquents in their service. The interviewed police officers confirmed the following links between internally displaced persons and increased crime rate in Ukraine: ${ }^{34}$

1. Internally displaced persons commit crimes on peaceful territories and return to the conflict area to escape punishment;

2. Low level of material support, absence of permanent residence and unemployment motivate internally displaced persons to commit profit directed crimes;

3. Among internally displaced persons there are a number of delinquents who after moving to peaceful territories didn't assimilate like law-abiding citizens and pursue their criminal activity.

There are no national statistics of internally displaced persons involved in criminal activity. In response to official request of Academician Stashis Scientific Research Institute for the Study of Crime Problems, the Office of Prosecution General informed that 727 offenses were committed by internally displaced persons in 2017. The most common offenses committed by this category of citizens are frauds, thefts, forgery of documents, stamps, seals or letterheads, and sale or use of forged documents. ${ }^{35}$

At the same time, the internally displaced population remains a vulnerable target for various illegal practices and infringements of human rights. According to the research conducted by the United Nations Refugee Agency, several internally displaced persons in Ukraine experienced security incidents linked to xenophobia. They reported threats, beatings, harassment, intimidation and lack of protection from the authorities, particularly the police. They described their impressions that as foreigners they are

34 Y. M. Tarasenko. Crimes of Internally Displaced Persons in Ukraine as a New Phenomenon of Criminal Reality. BULLETIN OF UZHGOROD NATIONAL UNIVERSITY. LEGAL SERIES 2. 2018. Pg. 94.

35 Response of the Office of Prosecutor General of Ukraine to the request of Academician Stashis Scientific Research Institute for the Study of Crime Problems, National Ukrainian Academy of Law Sciences, from 01-02-2017 №34/o/208-17/221. 
unable to obtain police protection or assistance. Consequently, they do not bother to report harassment or violent incidents. Such underreporting to the authorities conceals the real extent and severity of many acts of aggression against asylum seekers and refugees. ${ }^{36}$ These facts point at a high risk of victimization of internally displaced persons, who are not included in official victimological statistics, and their number can be only estimated by indirect research methods and social monitoring. The number of victims of crimes among refugees, stateless persons and illegal migrants can be acquired from official statistics of the Office of Prosecutor General of Ukraine (table 2; United Report on Criminal Transgressions, 2014, 2015, 2016, 2017 and 2018).

Table 2. Data on victims of crimes among foreign citizens in 2014-2018 ${ }^{37}$

\begin{tabular}{lcc}
\hline \multirow{2}{*}{ Year } & \multicolumn{2}{c}{ Victims among foreigners } \\
\cline { 2 - 3 } & $\begin{array}{c}\text { Total number } \\
\text { of foreigners }\end{array}$ & $\begin{array}{c}\text { Including refugees, stateless } \\
\text { persons and illegal migrants }\end{array}$ \\
\hline 2014 & 1,808 & 39 \\
\hline 2015 & 140 & 0 \\
\hline 2016 & 2,464 & 17 \\
\hline 2017 & 1,916 & 17 \\
\hline 2018 (first 8 months) & 1,795 & 3 \\
\hline
\end{tabular}

Source: Own preparation.

The provided statistic generalization demonstrates that there are no regular trends in the number of victims among such vulnerable categories of the population of refugees, stateless persons and illegal migrants. A sharp decline in a number of victims in 2015 can be explained by a reform in law enforcement sphere (termination of the militia and transfer of its functions to the organs of the National Police of Ukraine). By all means, a relatively low number of official victim statistics among refugees, stateless persons and illegal migrants does not provide an accurate picture, due to the reluctance of illegal migrants to report the committed crimes because of the fear to be deported.

A similar situation can be observed among internally displace persons, but their reluctance to report crimes can be explained by their justified disbelief in the Ukrainian law enforcement system, and by previous mischief and aggression suffered in their

36 The 2017 Participatory Assessment Report for refugees, asylum seekers, and internally displaced persons in Ukraine.

37 Based on the official statistics of detected crimes of the Office of Prosecutor General of Ukraine. Available at: www.gp.gov.ua/ua/stat.html 
status. Therefore, low or at times zero statistics of victims among the mentioned vulnerable categories of persons can be explained by high latency of the described illegal conduct, as well as unsatisfactory performance and low tolerance of Ukrainian law enforcement personnel.

Another urgent issue is connected to external irregular migration from the territories involved in the armed conflict. People in vulnerable circumstances agree to unofficial employment abroad and often become victims of human trafficking. According to La Strada research, about 8\% of irregular labor migrants agree to any kind of employment. It is also recorded that $30 \%$ of irregular labor migrants do not have any information on the risks of human trafficking. ${ }^{38}$ According to interviews of a random selection of five thousand Ukrainians in 2017 by the IOM, 54\% of Ukrainian citizens are absolutely sure that they are not a vulnerable target of human trafficking, $23 \%$ consider that they are unlikely to become victims of human trafficking, only $4 \%$ consider that there is a high probability of becoming a victim of human trafficking, and $19 \%$ refused to respond or had difficulties to answer. ${ }^{39}$ Ukrainian citizens fleeing from a conflict zone also generally do not consider themselves as probable targets of human trafficking.

Over the past few years, the Russian Federation became one of the most popular countries for irregular labor migration from Ukraine and, at the same time, with the highest rates of labor exploitation of migrants. Experts estimate that $66 \%$ (760 persons) of all victims (1.151) of human trafficking from Ukraine reside in the Russian Federation. ${ }^{40}$ Migrants were forced to work under the threat of being disclosed and arrested. This situation deteriorates by the fact that the Russian Federation did not sign the Council of Europe Convention on Action against Trafficking in Human Beings. According to the IOM, between 2014 and 2017 a total of 60,800 Ukrainian citizens have suffered from human trafficking. ${ }^{41}$ It is important to note that in recent

38 G. Stadnik. Migrants are among Potential Victims of Human Trafficking. Deutsche Welle. 10 April 2015.

39 Research on migration issues and human trafficking in Ukraine. 2017. Available at http:// iom.org.ua/sites/default/files/migration_and_human_trafficking_in_ukraine_2017_ukr. pdf

40 Y. V. Rakovska. Ukrainians as Potential Victims of Human Trafficking in the Republic of Poland. young SCIENTIST 30. 2016. Pg. 491; M. D. Romanyuk \& Z. V. Smutchak. State Policy on Counteracting Trafficking in People in Ukraine and Ways of its Enhancement. BULLETIN OF ZHYTOMIR STATE TECHNOLOgY UNIVERSITY 84. 2018. Pg. 46.

41 Research on migration issues and human trafficking in Ukraine. 2017. Available at http:// iom.org.ua/sites/default/files/migration_and_human_trafficking_in_ukraine_2017_ukr. pdf 
years the percentage of Ukrainian citizens suffering from human trafficking in the EU countries has increased from 15\% to 18\% (207 persons), 86\% of such incidents occurred in Poland. ${ }^{42}$

\subsection{Mercenarism as a common "satellite" of contemporary armed conflicts}

Another dimension of irregular migration is associated with crossing the state border with initial criminal intention. In the conditions of armed conflict in Ukraine, such instances include cases of mercenarism, joining terrorist and other unlawful paramilitary or armed organizations. There are documented cases of participation of foreign citizens besides citizens of the Russian Federation in the armed conflict; for instance, citizens of Belarus, Great Britain, France, Latvia, Serbia, Spain and even Brazil. The United Nations Working Group on the use of mercenaries on its Mission to Ukraine was informed of at least 176 of such cases. ${ }^{43}$

Foreign citizens cross the Ukrainian border unnoticed or on a legal basis and take part in the armed conflict on the side of unrecognized republics with different motivations (ideological, penchant for risk or simply for the purpose of pecuniary compensation). Illegally crossing the state border with criminal intent encompasses corpus delicti of newly adopted Art. 332-2 of the Criminal Code of Ukraine (crossing the state border of Ukraine with intent to cause harm to public interests), and practically falls under recently extended legal definition of irregular migration. The legal crossing of the state border by foreign citizens with the intent to join outlawed armed formations falls under a more loose criminological understanding of irregular migration, and must be taken into account when designing counteracting measures to this hazardous phenomenon.

Criminal activities of mercenaries are neither connected, nor authorized by governments of their home states. According to the International Convention against the Recruitment, Use, Financing and Training of Mercenaries in 1989, mercenarism is an offense of grave concern to all states and any person committing offenses connected with recruitment, use, financing and training of mercenaries should either be prosecuted or extradited. ${ }^{44}$ However, mercenaries are rarely held liable for committed misconduct. For instance, Serbian citizens who illegally crossed the Ukrainian border

42 Y. V. Rakovska, supra, note 43. Pg. 491.

43 Preliminary findings by the United Nations Working Group on the use mercenaries on their Mission to Ukraine.

44 International Convention against the Recruitment, Use, Financing and Training of Mercenaries, 1989. 
and participated in the armed conflict have thus far not been prosecuted. The Serbian Prosecutor's Office negotiated a conciliation agreement for Serbian mercenaries who took part in the armed conflict at Donbass region, since Lugansk Public Republic and Donetsk Public Republic had not been recognized as terrorist organizations by the United Nations Security Council. ${ }^{45}$

Ukraine so far also doesn't have a positive experience in convicting mercenaries. For example, the Office of Prosecutor General of Ukraine prosecuted a high-profile case of the Brazil citizen Raphael Lusvarghi, who participated in the armed conflict on the side of unrecognized republics. The prosecutor did not press charges for mercenarism and instead charged him with taking part in terrorist organizations (Art. 258-3 of the Criminal Code of Ukraine) and with participation in unlawful paramilitary formations (Art. 260 of the Criminal Code of Ukraine). ${ }^{46}$ Legal professionals admit extreme complexity in proving the mental element of mercenarism; so law enforcement agencies tend not to apply this norm. Therefore, there is no true statistics on proliferation of mercenarism in conditions of hybrid armed conflicts.

From the other side, there is evidence of exporting mercenary skills from Ukraine to other countries suffering from armed conflicts. ${ }^{47}$ Having acquired military experience on the side of unrecognized republics, some Ukrainian citizens travel to other states and join one of the conflicting sides for "making a fast buck". This identifies the necessity to enhance legal and organizational counteracting mercenarism both on national and international levels.

\section{CONCLUSION}

Irregular migration is a highly controversial phenomenon encompassing social, cultural, economic, political and legal aspects. This research made an effort to generalize legal and criminological concepts of irregular migration, outline its global and national tendencies, and analyze threats posed to be the contemporary forms of irregular migration to the national security of the state. Using different analytical methods based on the relevant statistics, it presented an author's view on the influence of irregular migration on law and order in society. The relevance of the research is emphasized by the presence of armed conflict in the Eastern territories of Ukraine and its direct and indirect influence on the rate and character of irregular migration in the state.

45 Why Serbian Mercenaries were not Strictly Punished?

46 Indictment of Pecherskij Regional Court of Kiev. Case № 757/2179/17-K.

47 "Putin's private army": Security Service of Ukraine encountered more than 50 Ukrainian mercenaries in "Vagner" group. 
The main objective of the research is to comprehend and examine the different dimensions of irregular migration, namely its criminogenic, victimological sources and its background influence on criminal processes in Ukraine. Recent amendments made to the Criminal Code of Ukraine officially extended the notion of irregular migration in Ukraine. At the same time, the wording of Arts. 332-1 and 332-2 of the Criminal Code of Ukraine nowadays is too loose and requires restriction of criminal liability to violations of border regime with the intent to commit serious offenses against the national security of Ukraine and public order. The main findings of the research may be outlined as following: The lack of official attention to the issue of irregular migration encompassing all of the examined dimensions may lead to potentially greater criminal problems. In the author's view, international and geopolitical aspects of irregular migration are currently underestimated.

The research also examines mercenarism as a type of illegal irregular migration activity and, at the same time, as one of considerable threat to the national security of the state in conditions of armed conflict. It emphasizes the importance of addressing both internal and external hazards of mercenarism and enhancing counteracting measures at national and international levels.

Hazards posed by irregular migration in conditions of armed conflict are still relatively novel. Currently, providing a criminological review and drawing up a well-founded prognosis in this field is a task of paramount importance. Therefore, issues of irregular migration in conditions of armed conflict require further research.

The observations above could lead to the conclusion that irregular migration poses a number of criminogenic risks to Ukrainian national security, as well as to the rights and freedoms of Ukrainian citizens, especially of those who remain or arrive to the occupied territories. Decreasing the risks of irregular migration can be achieved by:

- $\quad$ Resolving the issue on the legal status of the armed conflict in Eastern regions of Ukraine, as well as recognizing Lugansk Public Republic and Donetsk Public Republic as terrorist's organizations on the national level;

- Reinforcing suppression of all kinds of smuggling, international as well as with the occupied territories;

- $\quad$ Providing legal and psychological support to the victims of human trafficking and internally displaced persons;

- Intensification of awareness-raising campaign on the risks on migrant smuggling and human trafficking among Ukrainian citizens, including the population of the affected conflict regions; 
- $\quad$ Reinforcing the fight against organized crime, paying specific attention at counteracting ethnic minority criminality;

- Further enhancing organizational bases and legal support in the field of counteracting irregular migration.

\section{REFERENCES}

A. A. Nikitin. Criminal Responsibility for Violation of Procedure for Temporary Occupied TERRITORY OF UKRAINE ENTRY AND EXIT FROM IT. National Academy of Internal Affairs. (2018).

G. Stadnik. Migrants are among Potential Victims of Human Trafficking. Deutsche Welle. 10 April 2015.

International Organization for Migration. ILlegal Migration IN EASTERn EUROPE AND UkRaine. SPECIAL RePORT. IOM Publications. (2018).

J. P. Bjelopera \& K. M. Finklea. Organized Crime: An Evolving Challenge for U.S. Law Enforcement. CRS Report for Congress. 2012.

O. Baganets. Crime without Borders. Crime Statistic, its Structure and Dynamics on the Territory of Ukraine in 2017 (Comparative to Crime Rate in 2009, 2010, 2013-2016). Available at: http://baganets.com/blogs-baganets/zlochinn-st-bez-kordon-v.html

T. A. Denisova. Migration Processes in Ukraine: Present State and Issues of Illegal Migration. STATE ANd Regions. Legal SeRIEs 2. 2016.

T. Y. Ognyev. Illegal Migration: Criminal-Legal and CRiminological Aspects. Kyiv International University. (2017).

United Nations. Human Development Report. "OVercoming BARRIers: Human mobility ANd deVeLOPMENT". United Nations Publications. (2009).

United Nations High Commissioner for Refugees. UNHCR urges Ukraine to establish central registration system as internal displacement tops 117,000. 5 August 2014. Available at: www.unhcr. org/news/latest/2014/8/53e0b3a59/unhcr-urges-ukraine-establish-central-registration-system-internal-displacement.html

V. G. Sevruk. The Notion and Criminal Legal Characteristic of "Ethnic Criminality" in Ukraine. JournaL of AdVOCACY ACADEMY OF UKRAINE 24. 2014. 
V. G. Sevruk \& N. K. Makarenko. Counteracting Ethnic Organized Crime Activity by Law Enforcement Organs of Ukraine: Ukrainian and International Experience. SCIENTIFIC BULLETIN OF NATIONAL ACADEMY OF INTERNAL AFFAIRS 103. 2017.

Y. V. Rakovska. Ukrainians as Potential Victims of Human Trafficking in the Republic of Poland. Young SCIENTIST 30. 2016. Pg. 491; M. D. Romanyuk \& Z. V. Smutchak. State Policy on Counteracting Trafficking in People in Ukraine and Ways of its Enhancement. BULLETIN OF ZHYTOMIR STATE TECHNOLOGY UNIVERSITY 84. 2018.

Y. M. Tarasenko. Crimes of Internally Displaced Persons in Ukraine as a New Phenomenon of Criminal Reality. Bulletin of Uzhgorod National University. Legal Series 2. 2018. 